\title{
Conceptual Site Model for Newark Bay-Hydrodynamics and Sediment Transport
}

\author{
Parmeshwar L. Shrestha ${ }^{1, *}$, Steave H. Su ${ }^{2}$, Scott C. James ${ }^{1}$, Philip J. Shaller ${ }^{1}$, Macan \\ Doroudian $^{1}$, Clifford E. Firstenberg ${ }^{3}$ and Carlie T. Thompson ${ }^{3}$
}

1 Exponent, Inc., 320 Goddard, Suite 200, Irvine, CA 92618, USA;

E-Mails: sjames@exponent.com (S.C.J.); pshaller@exponent.com (P.J.S.); mdoroudian@exponent.com (M.D.)

2 Exponent, Inc., 420 Lexington Avenue, Suite 1740, New York, NY 10170, USA;

E-Mail:ssu@exponent.com

3 Tierra Solutions, Inc., 2 Tower Center Boulevard, 10th Floor, East Brunswick, NJ 08816, USA; E-Mails: clifford.firstenberg@tierra-inc.com (C.E.F.); carlie.thompson@tierra-inc.com (C.T.T.)

* Author to whom correspondence should be addressed; E-Mail: pshrestha@exponent.com; Tel.: +1-949-242-6037; Fax: +1-949-242-6099.

Received: 6 December 2013; in revised form: 21 January 2014 / Accepted: 10 February 2014 / Published: 19 February 2014

\begin{abstract}
A conceptual site model (CSM) has been developed for the Newark Bay Study Area (NBSA) as part of the Remedial Investigation/Feasibility Study (RI/FS) for this New Jersey site. The CSM is an evolving document that describes the influence of physical, chemical and biological processes on contaminant fate and transport. The CSM is initiated at the start of a project, updated during site activities, and used to inform sampling and remediation planning. This paper describes the hydrodynamic and sediment transport components of the CSM for the NBSA. Hydrodynamic processes are influenced by freshwater inflows, astronomical forcing through two tidal straits, meteorological conditions, and anthropogenic activities such as navigational dredging. Sediment dynamics are driven by hydrodynamics, waves, sediment loading from freshwater sources and the tidal straits, sediment size gradation, sediment bed properties, and particle-to-particle interactions. Cohesive sediment transport is governed by advection, dispersion, aggregation, settling, consolidation, and erosion. Noncohesive sediment transport is governed by advection, dispersion, settling, armoring, and transport in suspension and
\end{abstract}


along the bed. The CSM will inform the development and application of a numerical model that accounts for all key variables to adequately describe the NBSA's historical, current, and future physical conditions.

Keywords: Newark Bay; conceptual site model; hydrodynamics; sediment transport

\section{Introduction}

Since the late 1800s, Newark Bay and adjoining waterways located in New Jersey, USA, have been highly industrialized, receiving direct and indirect discharges from numerous industrial facilities. A Remedial Investigation/Feasibility Study (RI/FS) under the Comprehensive Environmental Response, Compensation, and Liability Act (CERCLA "Superfund") began in 2004 for the Newark Bay Study Area (NBSA) - which has been defined as Newark Bay (the Bay) and portions of the Hackensack River, Arthur Kill, and Kill van Kull (Figure 1).

To initiate the field investigations for the NBSA, Tierra first developed a Preliminary Conceptual Site Model (CSM) [1], based on historical data, and used the model to plan the first two phases of the remedial investigation (RI) $[1,2]$. The new data generated from these investigations were used to create the revised CSM described herein, to inform additional data needs for the RI. The specific objectives of the CSM include:

- Update the current understanding of the conditions and processes in the NBSA based on the data generated from recent RI investigations [1,2] and secondary data [3,4].

- Guide the planning and development of future sampling and investigation activities as part of the RI/FS program, including both the human health and ecological risk assessments.

- Provide further insight into the sources of hazardous substances or contaminants of potential concern (COPCs) to the NBSA and its adjoining tributaries.

The comprehensive NBSA CSM addresses: (1) the general physico-chemical characteristics of the NBSA (including geology and geomorphology, surface water quality, biological communities), as well as (2) contaminant sources, (3) hydrodynamics and sediment transport, (4) contaminant fate and transport, (5) nature and extent of sediment contamination, (6) human and ecological exposure pathways, and (7) identification of data gaps. The focus of this paper is the hydrodynamics and sediment transport components of the NBSA CSM.

\section{Environmental History of the Newark Bay Study Area}

Newark Bay is situated within a highly industrialized and heavily populated region, adjacent to the cities of Newark and Elizabeth. It is bordered by Newark Liberty International Airport to the west; Jersey City and Bayonne to the east; and Staten Island, New York, to the south. As part of the New York/New Jersey Harbor Estuary, Newark Bay has evolved over more than two centuries into a key shipping port and a convenient site for industrial operations [5-9]. 
Figure 1. Regional map of Newark Bay and the Newark Bay Study Area (NBSA) outlined in green.

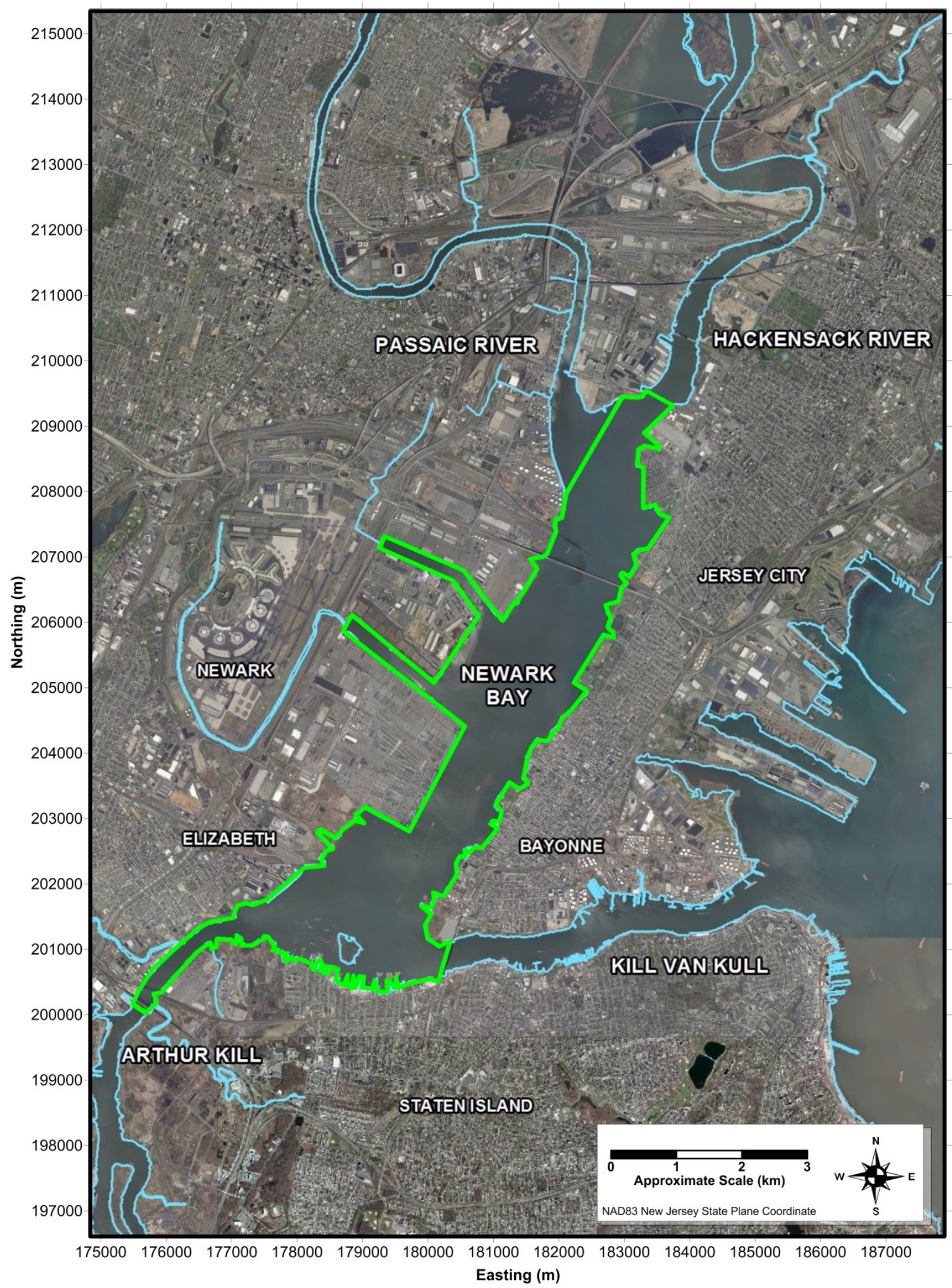


Environmental degradation has occurred in the NBSA over the past two centuries due to a variety of factors - including shoreline and land development [10], wetlands destruction, habitat degradation, garbage and sewage disposal, and releases of contaminants [11]. As a result of urban and industrial practices, the NBSA is contaminated with a number of COPCs - including polychlorinated biphenyls (PCBs), polycyclic aromatic hydrocarbons (PAHs), pesticides, herbicides, volatile and semivolatile organic compounds (VOCs and SVOCs, respectively), polychlorinated dibenzo- $p$-dioxins and polychlorinated dibenzofurans (PCDDs and PCDFs), and metals [12,13].

\section{Conceptual Site Model-Hydrodynamics and Sediment Transport}

The NBSA is a partially mixed estuary that receives large freshwater contributions from the Passaic and Hackensack Rivers at the northern end of the Bay and additional freshwater contributions from a number of other tributaries, combined sewer overflows (CSOs), storm water outfalls (SWOs), and publically owned treatment works (POTWs) distributed throughout the Bay. It also receives salt water contributions through the Kill van Kull and the Arthur Kill tidal straits at the southern end of the Bay. The NBSA and the surrounding area have a long history of human activity that has modified the shorelines and bathymetry of Newark Bay and its tributaries. As a result, the Bay's bathymetry consists of shallow tidal flats adjacent to deeper, dredged navigation channels, which results in a complex bathymetry with sharp elevation gradients. Large bathymetric gradients, highly variable freshwater loading, astronomical tides, and prevailing and event-based meteorological forcing all contribute to the system's complex hydrodynamic and sediment transport patterns and processes.

\subsection{Hydrodynamics}

The hydrodynamics of Newark Bay are influenced primarily by three physical processes: (1) freshwater tributary flows; (2) astronomical forcing (including classical estuarine gravitational circulation) through the Kill van Kull and Arthur Kill tidal straits; and (3) local and regional meteorological events [14,15]. These primary influences combine to yield complex, event-driven circulation and make it challenging to identify a long-term average pattern [16].

A substantial amount of dredging has been done over the past 150 years [10], and flows are much different now in Newark Bay from what they were before human activities began. In general, it is understood that, because of the freshwater inputs in the northern end of the Bay, the system is partially mixed and displays the characteristics of classic two-layer estuarine circulation with a landward flow of salt water in the bottom layer and a seaward flow of less saline water in the surface layer [15-18]. High freshwater discharge from the Passaic River increases both vertical stratification and flow rate in the landward-flowing, saline bottom layer in Newark Bay [16].

This estuarine gravitational circulation pattern can be interrupted (i.e., daily-averaged currents become uniform with depth) during periods of very low freshwater discharge from the Passaic River or during strong meteorological events [16,19]. Moreover, the consensus view in published literature is that there is, on average, a counterclockwise circulation around Staten Island [20-22]. In addition, because the Kill van Kull is shorter, straighter, and better aligned with tidal and gravitational forcing, it typically experiences flows about an order of magnitude greater than the Arthur Kill [23]. Because of 
the complexity and variability of the circulation patterns, it is most efficient to examine individually the responses of the NBSA to each of the primary influences.

\subsubsection{Tributary Inflows}

Freshwater is delivered to Newark Bay through a number of major and minor waterways (Figure 2). The principal sources of freshwater are the Passaic [24] and Hackensack Rivers [25] with mean daily discharges of $47 \mathrm{~m}^{3} / \mathrm{s}\left(1500 \mathrm{ft}^{3} / \mathrm{s}\right)$ and $6 \mathrm{~m}^{3} / \mathrm{s}\left(218 \mathrm{ft}^{3} / \mathrm{s}\right)$, respectively. Minor contributors include the Peripheral Ditch and Piersons Creek (no flow data available), which empty directly into the Bay. The Rahway and Elizabeth Rivers, Piles Creek, Morses Creek, Old Place Creek and Fresh Kills Creek enter the Bay by way of the Arthur Kill tidal strait. The mean daily discharges from Rahway River [26], Elizabeth River [27], Morses Creek [28] and Fresh Kills Creek [29] are $1.2 \mathrm{~m}^{3} / \mathrm{s}\left(41 \mathrm{ft}^{3} / \mathrm{s}\right), 0.7 \mathrm{~m}^{3} / \mathrm{s}$ $\left(24 \mathrm{ft}^{3} / \mathrm{s}\right), 0.06 \mathrm{~m}^{3} / \mathrm{s}\left(2 \mathrm{ft}^{3} / \mathrm{s}\right)$, and $0.4 \mathrm{~m}^{3} / \mathrm{s}\left(14 \mathrm{ft}^{3} / \mathrm{s}\right)$; the remaining waterways (Piles Creek and Old Place Creek) do not have flow data available. Two other waterways, Oyster Creek and Maple Island Creek, formerly drained to the Bay (circa 1917), but have since been filled. Figure 2 shows the magnitude of the peak freshwater inflows into the NBSA, wherein the size of the open arrows qualitatively indicates the magnitude of the peak flows. The solid arrows indicate the typical flow direction of estuarine circulation during flood tide (red arrows are bottom salt water flows, and blue arrows are freshwater surface flows).

\subsubsection{Point Sources (CSOs, SWOs, and POTWs)}

In addition to these freshwater tributaries, there are also significant anthropogenic freshwater inputs to Newark Bay, including urban runoff, CSOs, SWOs, and POTWs. Suszkowski [18] reported undifferentiated industrial and municipal wastewater discharges totaling $6.6 \mathrm{~m}^{3} / \mathrm{s}\left(232 \mathrm{ft}^{3} / \mathrm{s}\right)$ to Newark Bay. HydroQual Inc. [30] subsequently reported wastewater discharges during 1989, yielding a combined total of $13.4 \mathrm{~m}^{3} / \mathrm{s}\left(474 \mathrm{ft}^{3} / \mathrm{s}\right)$ of industrial and municipal runoff into tributaries of Newark Bay during that year. Another estimate places freshwater flows into the Arthur Kill from sewage treatment plants at $4.8 \mathrm{~m}^{3} / \mathrm{s}$ or $\left(170 \mathrm{ft}^{3} / \mathrm{s}\right)$, and from permitted industrial discharges at $0.5 \mathrm{~m}^{3} / \mathrm{s}\left(18 \mathrm{ft}^{3} / \mathrm{s}\right)$ into the Arthur Kill [29]. A more recent approximation indicates that the Bergen County POTW and Secaucus POTW discharge an average of $3 \mathrm{~m}^{3} / \mathrm{s}\left(108 \mathrm{ft}^{3} / \mathrm{s}\right)$ and $0.15 \mathrm{~m}^{3} / \mathrm{s}\left(5.3 \mathrm{ft}^{3} / \mathrm{s}\right)$, respectively, to the Hackensack River [31].

\subsubsection{Non-Point Sources (Direct Runoff and Groundwater)}

The State of New Jersey's annual rainfall typically ranges between $813 \mathrm{~mm}$ (32 in.) and $1219 \mathrm{~mm}$ (48 in.) with an average of $1151 \mathrm{~mm}$ (45.3 in.) from 1895 to 2012 [32]. Newark averages slightly more rain at $1174.8 \mathrm{~mm} /$ year (46.25 in./year) [33]. Most of the rain falling on the Newark Bay watershed eventually enters the Bay in the form of runoff or groundwater influx, the amount of which is highly variable and dependent on the annual climatic conditions. 
Figure 2. Freshwater flows into the NBSA where the size of the open arrows reflects the relative magnitude of the flows.

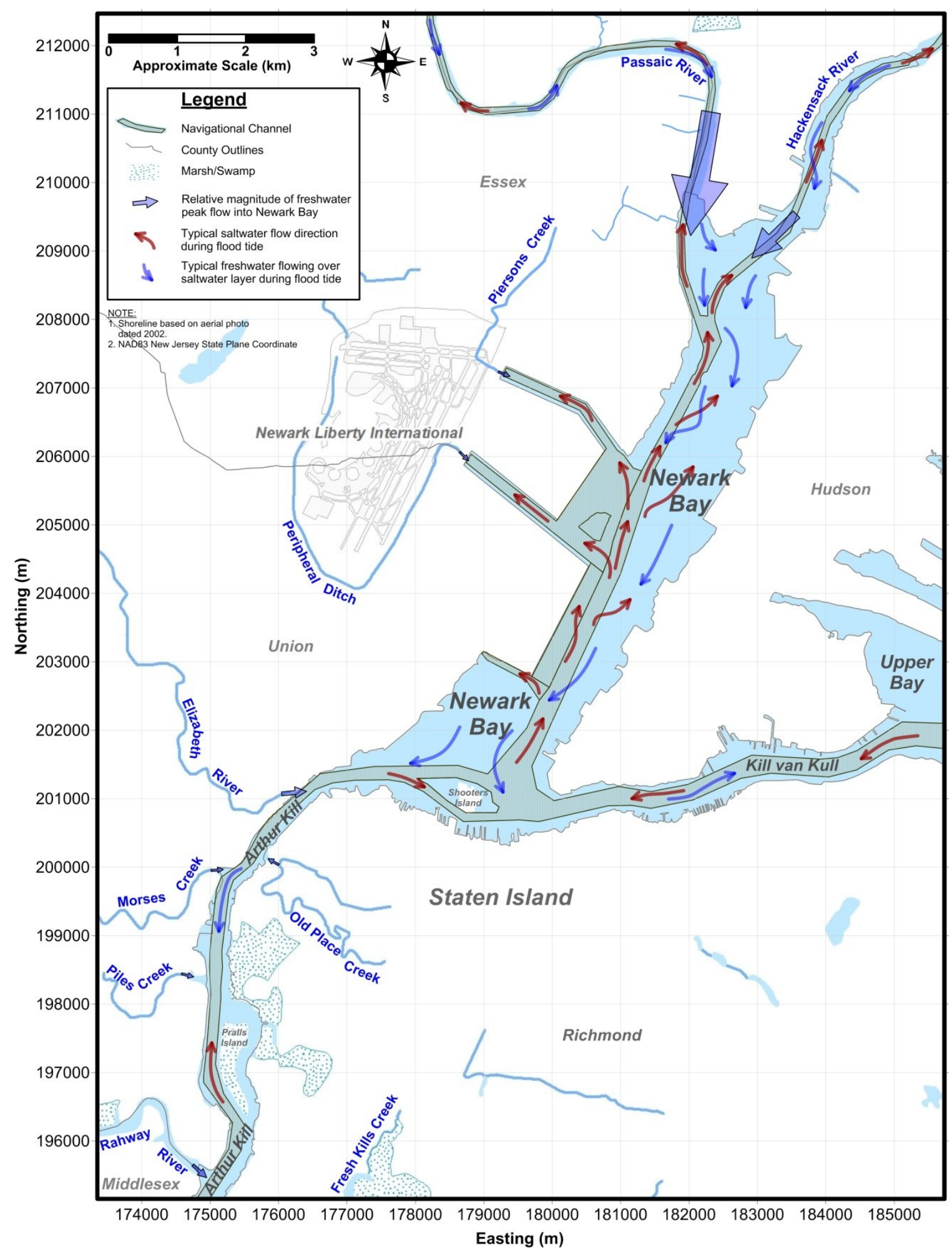

\subsubsection{Flows through the Tidal Straits}

Newark Bay is connected to the Atlantic Ocean by two straits: the Kill van Kull on the southeast and the Arthur Kill on the southwest. The Kill van Kull connects Newark Bay to the Upper Bay of New York Harbor (to the east), while the Arthur Kill connects Newark Bay to Raritan Bay (to the 
south). The combination of tidal forcing, significant freshwater flows from the Passaic and Hackensack Rivers, and dredged navigational channels results in measurable salinity stratification within both tidal straits, yielding daily-averaged, two-layer subtidal flow patterns with seaward flows of less saline water near the surface that are offset by landward flows of saltier water near the bottom [16,22,34].

The Kill van Kull is a tidally dominated strait where the tidal excursion (distance that water travels over half a tidal cycle) is much greater than its length. Because of its relatively short length, the Kill van Kull exhibits strong currents and relatively weak stratification (up to $1.5 \mathrm{psu}$ ), promoting a greater degree of tidal exchange and mixing between Newark Bay and New York Harbor than occurs between Newark Bay and Raritan Bay by way of the Arthur Kill [16,35]. The movement of water through the Arthur Kill is impeded relative to the Kill van Kull, because the tidal excursion is shorter than its length. Its freshwater sources support a mild vertical salinity gradient of up to 1 psu. LMS [36] estimated tidal flows through the Kill van Kull and the Arthur Kill to occasionally exceed $1417 \mathrm{~m}^{3} / \mathrm{s}$ $\left(50,000 \mathrm{ft}^{3} / \mathrm{s}\right)$ and $283 \mathrm{~m}^{3} / \mathrm{s}\left(10,000 \mathrm{ft}^{3} / \mathrm{s}\right)$, respectively, with average flows passing through Kill van Kull ranging up to an order of magnitude larger than those passing through Arthur Kill [23].

\subsubsection{Gravitational Circulation and Tidal Currents}

Flows through the tidal straits are a result of both salinity gradients (gravitational circulation) and water-elevation differences (tidal current) between the ends of each strait (meteorological forcing also plays an important role). Freshwater inflow, primarily from the Passaic and Hackensack Rivers, supports both the gravitational circulation and tidal current mechanisms. Figure 3 is a schematic of the two-layer circulation in the NBSA. Red arrows indicate salt water flow, and blue arrows freshwater flow. For the relatively larger inputs, the numbers near each arrow indicate the volumetric inflow over a tidal cycle as a fraction of the estimated volume of the Bay (with water at sea level). The Kill van Kull and Arthur Kill straits tend to form a through-flow pattern of circulation around Staten Island, in contrast to a tidal pumping mode of circulation in which Newark Bay is filled (or emptied) by simultaneous inflow (or outflow) through both Kills $[16,19,20]$.

\subsubsection{Meteorological Forcing}

Although tidal circulation patterns through the Kill van Kull and the Arthur Kill are generally counterclockwise around Staten Island [20], strong and persistent meteorological events can, at times, dominate the circulation pattern in Newark Bay, as well as the magnitude and direction of flows in the Kill van Kull and the Arthur Kill [16,17,29,37,38]. The primary types of storms that affect Newark Bay include tropical storms that typically occur in late summer and fall, and extra-tropical ("Nor'easter") storms that occur primarily in the winter. The extra-tropical storms can cause high water levels and enhanced wave conditions. Potential wave heights can be over $1.8 \mathrm{~m}(6 \mathrm{ft})$ for the

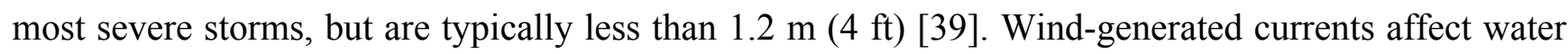
mixing and possibly sediment transport within Newark Bay [39]. Strong wind events were also shown to generate large episodic flushing. 
Figure 3. Schematic of the two-layer circulation pattern in the NBSA.

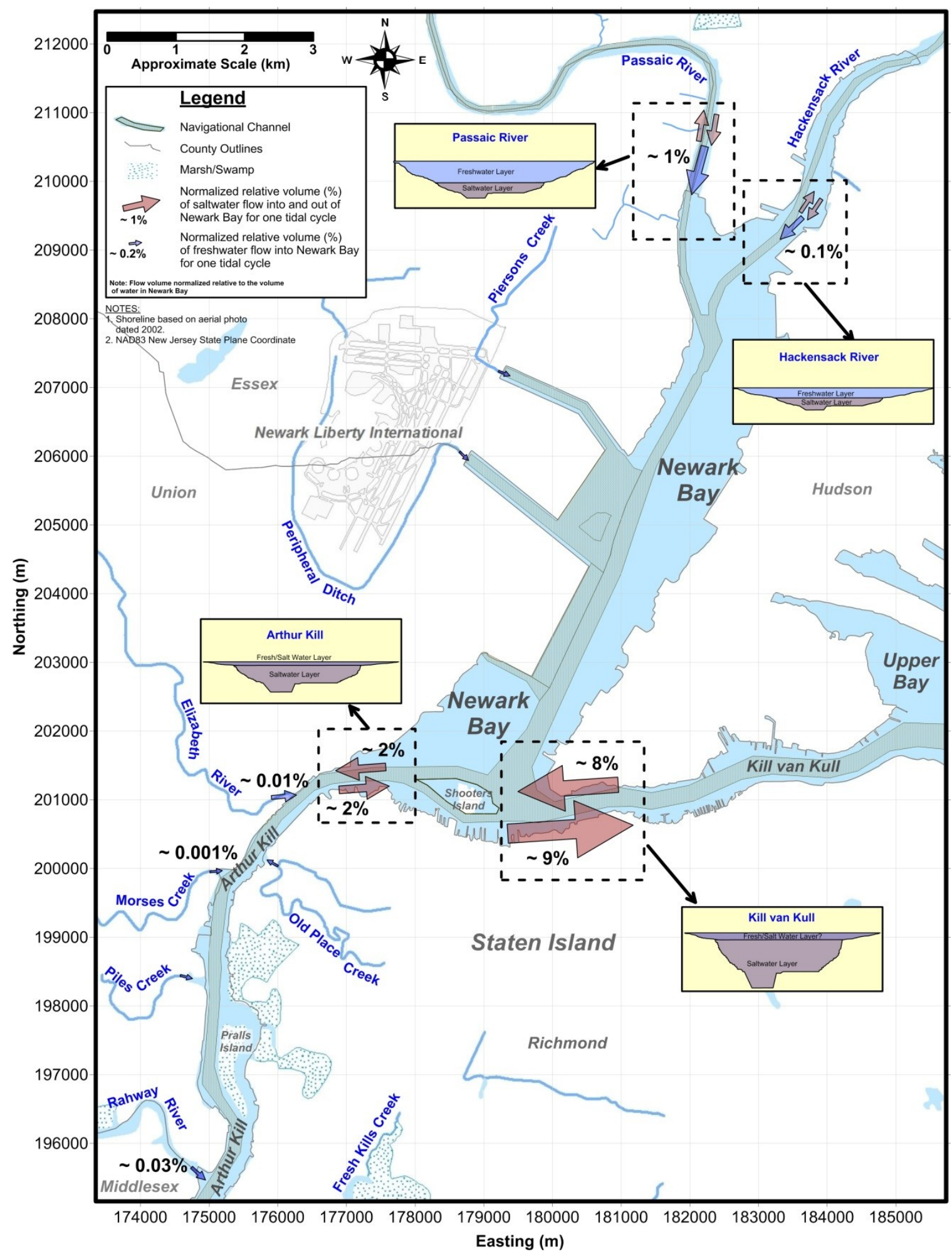

\subsection{Sediment Dynamics}

Sediment dynamics in estuarine environments such as the NBSA are driven by several factors, including hydrodynamics, episodic meteorological events, sediment loading from freshwater inflows, sediment loading at open boundaries, sediment size gradation, bed sediment properties, bioturbation, and particle-to-particle interactions. Significant human activities including long term maintenance and 
navigational dredging and ship traffic also affect sediment dynamics. A significant volume of research has been conducted to better understand the role that tidal circulation patterns and wind-driven episodic events play in the fate and transport of sediments within the NBSA [15,16,18,19,22,34,37,38,40]. Fluid mud transport is not considered in this CSM because site characterization data collected to date have not indicated the presence of fluid mud. In addition, no previous publication related to the NBSA has considered the effects of fluid mud as a potential transport pathway for sediments and associated contaminants. Until such processes are observed, there is no basis to include them in the CSM.

\subsubsection{Sediment Transport Processes}

A schematic of the processes that influence sediment transport in the water column and the sediment bed of the NBSA is shown on Figure 4. Local advection and dispersion in the water column control the distribution of sediment particles throughout the system. Advection moves the sediments according to the local water velocity while dispersion spreads sediments based on concentration gradients. Sediments are typically classified as either cohesive (small grain sizes) or noncohesive (larger grain sizes). Cohesive sediments are composed primarily of clay-sized $(<2 \mu \mathrm{m})$ and silt-sized $(<63 \mu \mathrm{m})$ particles, mixed with organic matter and sometimes small quantities of very fine sand. Noncohesive sediments are primarily sand and gravel-sized materials $(>63 \mu \mathrm{m})$. Each sediment class is subject to different physical processes [41-43].

Figure 4. Schematic of sediment transport processes where $C$ is the suspended sediment concentration profile, $U$ is the velocity profile, $\tau_{b}$ is the bed shear stress, and $u_{*}$ is the shear velocity. Concentration and velocity profiles are conceptual only. The concentration profile reflects increased sediment concentration with depth, and the velocity profile decreases to zero at the sediment bed.

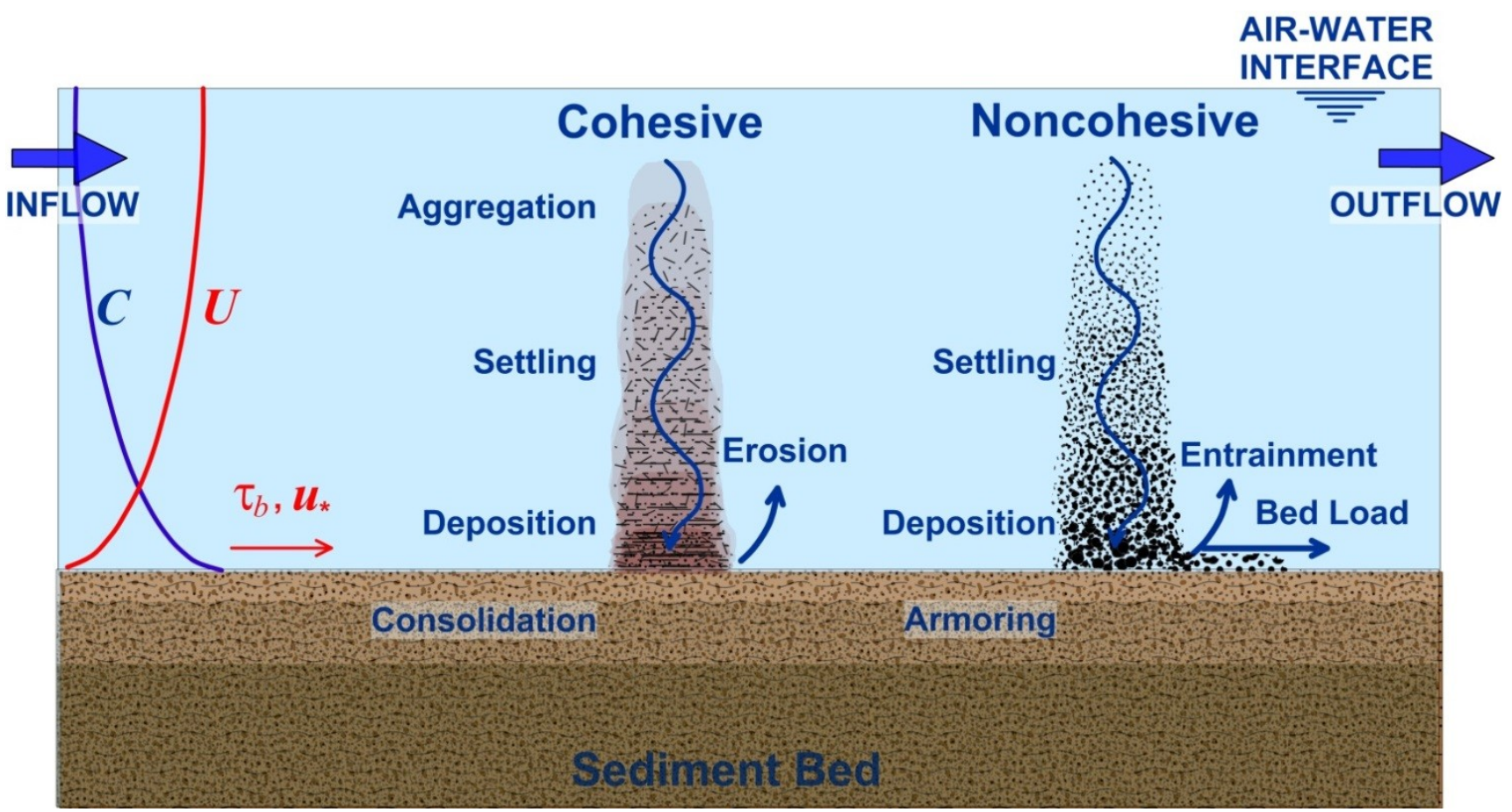




\subsubsection{Bed Shear Stresses}

Hydrodynamic flows will result in variable shear stresses at the sediment bed that, depending upon erodibility, may lead to erosion. When wind-waves are present, it is necessary to account for the shear stress on the sediment bed caused by wave-current interaction, which is a function of the bottom orbital amplitude and bottom orbital currents, both of which depend on the wave climate $[44,45]$. Including the effect of waves is necessary because the bed shear stresses can be an order of magnitude greater than stresses caused by currents alone. Vessel-generated wakes, associated with tugs, barges, and deep-draft vessel traffic in the Navigation Channels, represent another source of wave action in the Bay [10,15]. Although minor compared to wind-waves, these waves can also contribute to the resuspension of bottom sediments in shallow Subtidal Flat areas. Ship traffic can also resuspend sediments in the deeper dredged portions of the channel due to prop wash.

\subsubsection{Sediment Loading}

In terms of general sediment inputs to the NBSA, LMS [36] estimated that the Kill van Kull and the Arthur Kill provide approximately $60 \%$ and $12 \%$ of the total sediment load to the Bay, respectively. The Passaic and Hackensack Rivers deliver 23\% and 2\% of the total sediment load, respectively. Other sources of sediment to Newark Bay include POTWs (Bergen County and Secaucus), CSOs, SWOs, and atmospheric deposition, which are estimated to deliver a combined total of approximately $3 \%$ of the total sediment load [36]. Figure 5 shows the relative magnitude of the sediment loading to the NBSA (scaled by the percentages listed above). These estimates are similar to those of Suszkowski [18], Lowe et al. [31], and Sommerfield and Chant [22]. The two notable differences are that Sommerfield and Chant [22] and Pence [17] suggest that the Arthur Kill is a net exporter of sediment, and that Suszkowski [18] found the Hackensack to be a net sink for Bay sediments. There is significant variability across the estimates, the consequence of which is that there is appreciable uncertainty in the annual sediment input to Newark Bay. Table 1 lists published sediment loading estimates for the Passaic River into Newark Bay.

Sediment transport modeling conducted by Wakeman III [15] and sediment transport observations by Sommerfield and Chant [22] suggest that suspended sediments in the upper portion of the Bay do not leave the Bay during ebb tide or during periods of normal freshwater discharge to the Bay, and only up to about $15 \%$ of sediments in the lower portion of the Bay might exit the system. Sommerfield and Chant [22] evaluated suspended sediment deposition patterns during a Passaic River high-flow event and found that sediment deposition from such an event was greatest in the northern portions of the Bay, primarily within the Navigation Channel, with little evidence of flood-tide-related deposition on the Subtidal Flats. In the southern portion of the Bay, Sommerfield and Chant [22] indicate that most of the Kill van Kull sediment influx is not carried into the northern portion of the Bay. This suggests that Newark Bay experiences a localized convergence of sediment flux (deposition), which is consistent with the hypothesis [22] that the historical dredging of the Bay is required because otherwise the system tends to return to its natural, shallow state. 
Figure 5. Sediment loads to the NBSA where the size of the arrows reflects the relative magnitude of sediment loading.

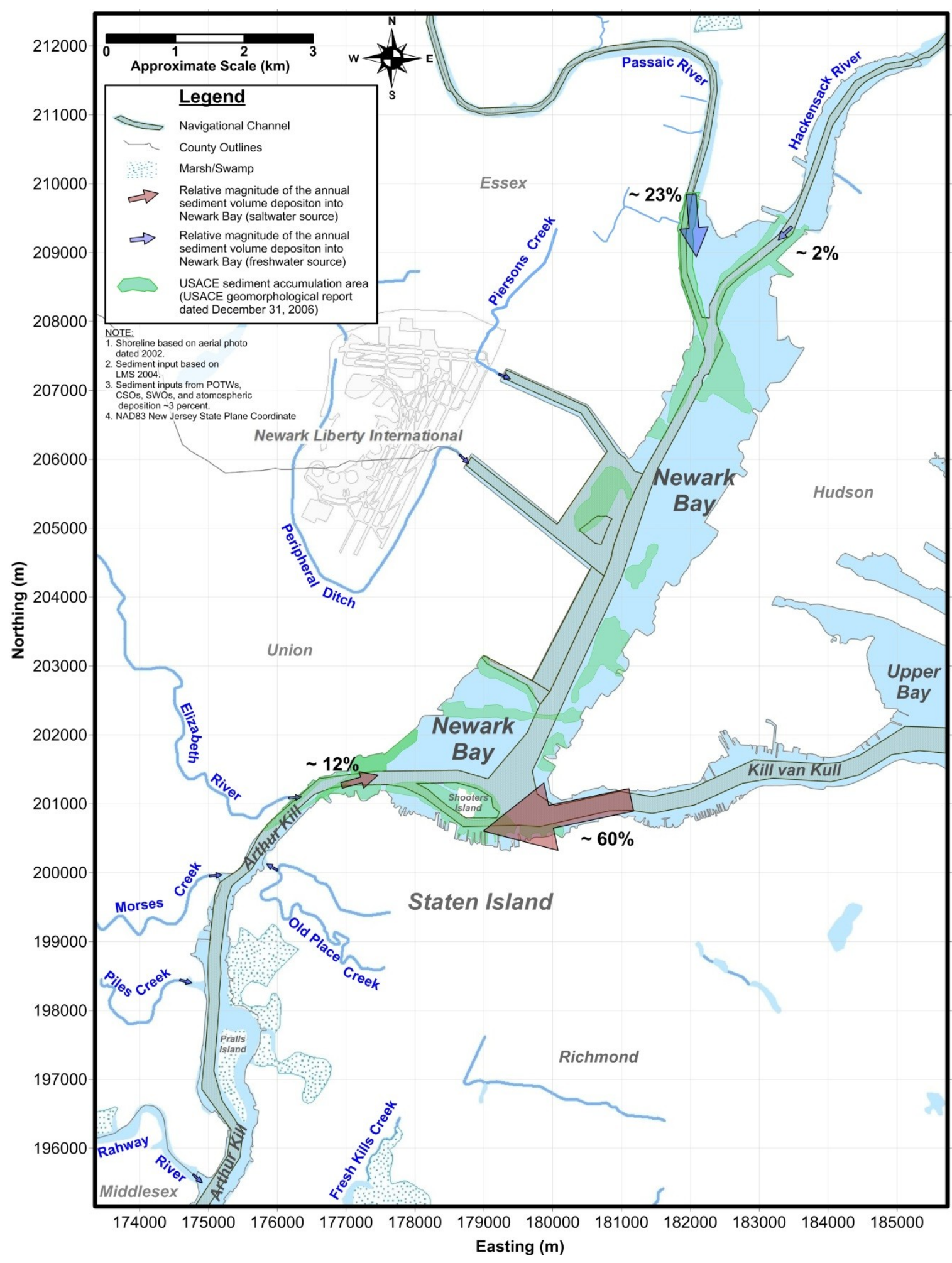


Table 1. Passaic River sediment loading rates.

\begin{tabular}{ccc}
\hline Source & Load (MT/year) & Analysis \\
\hline Table 4-7 in [46] & 7440 & Solids balance $^{1}\left(0.6 \mathrm{MT}_{\text {yard }}{ }^{3}\right)$ \\
page 1 in [22] & 17,000 & Sediment flux data $^{2}$ \\
Table 10 in [18] & 18,100 & Sediment flux data $^{2}$ \\
Table 4-7 in [46] & 21,360 & Chemical balance $^{3}\left(0.6 \mathrm{MT}_{\text {yard }}{ }^{3}\right)$ \\
page 1 in [47] & 22,700 & Sediment flux data $^{2}$ \\
page 35 in [16] & 30,000 & Sediment flux data $^{2}$ \\
Table 5-3 in [30] & 30,790 & Sediment flux data $^{2}$ \\
Table 3-5 in [15] & 36,109 & Sediment runoff data $^{4}$ \\
Table 3 in [31] & 47,456 & Sediment flux data $^{5}$ \\
\hline
\end{tabular}

${ }^{1}$ Based on measured sediment flux data; ${ }^{2}$ Based on a solids balance of sediment loads through the Dundee Dam from Lowe et al. [31] with deposition of $2.54 \mathrm{~cm} /$ year (1 in./year) along the Passaic River; ${ }^{3}$ Based on the chemical mass balances of 2,3,7,8-tetrachlorinated-p-dibenzodioxin (TCDD) and total TCDD of the solids mass balance in note $1 ;{ }^{4}$ Based on a sediment yield of $39 \mathrm{MT} / \mathrm{km}^{2} /$ year for the Passaic River watershed; ${ }^{5}$ Based on measured sediment flux data; however, it is not clear if these are tons/year or MT/year.

\subsubsection{Historical and Ongoing Dredging Activities}

As documented in USACE [16], the volume of the Navigation Channels excavated in Newark Bay has continually grown since the early 1900s. Moreover, substantial dredging is required simply for maintenance of the existing channels.

Olsen et al. [48] reported that the average annual dredge volume (Newark Bay, the Kills, and the Passaic and Hackensack Rivers) measured by the USACE in 1942-1973 was 439,864 $\mathrm{m}^{3} /$ year (575,320 yard ${ }^{3} /$ year; $220,000 \mathrm{MT} /$ year assuming $0.5 \mathrm{~g} / \mathrm{cm}^{3}$ dry density). This volumetric rate is higher than that reported by Lowe et al. [31], who evaluated USACE data from 1924 to 1985 and reported that the average annual dredge volume for 1953-1985 (when the channels were fairly stable) was $161,680 \mathrm{~m}^{3} /$ year $\left(211,469 \mathrm{yard}^{3} /\right.$ year or $80,840 \mathrm{MT} /$ year). Moreover, Lowe et al. [31] also reported estimates from the Port Authority of New York and New Jersey, because they dredged a significant additional amount of $100,388 \mathrm{~m}^{3} /$ year (131,303 yard 3 year or 50,194 MT/year). After studying several sources of information, Wakeman III [15] concluded that the majority of the annual sediment load of $276,000 \mathrm{~m}^{3} /$ year $\left(361,000 \mathrm{yard}^{3} /\right.$ year or $138,000 \mathrm{MT} /$ year) is being removed by maintenance dredging operations in the USACE channels and private berths totaling $262,000 \mathrm{~m}^{3} /$ year $\left(342,683\right.$ yard $^{3} /$ year or $131,000 \mathrm{MT} / \mathrm{year})$. It is the general consensus that the Navigation Channels in Newark Bay are the ultimate sinks for most fine-grained sediments entering the Bay, while the tidal flats are only temporary repositories for sediments that are subsequently resuspended for deposition into the Navigation Channels or for export.

More recently, the Port Authority of New York and New Jersey's Harbor Deepening Project (HDP) included dredging the channels from the Ambrose Channel entrance to the Upper Bay and Newark Bay, providing access to the Global Marine Terminal, New York Container Terminal, Port Newark, and Elizabeth Marine Terminal. Over 2,752,397 $\mathrm{m}^{3}$ (3,600,000 yard $\left.{ }^{3}\right)$ will be dredged by 2014. In 2011, 405,979 $\mathrm{m}^{3}\left(531,000 \mathrm{yard}^{3}\right)$ was dredged from Newark Bay. By 2013, 298,940 $\mathrm{m}^{3}$ $\left(391,000 \mathrm{yard}^{3}\right)$ of silt and $1,070,377 \mathrm{~m}^{3}\left(1,400,000 \mathrm{yard}^{3}\right)$ of clay, sand, and blasted rock were 
dredged from the Arthur Kill. The HDP channels constitute $21 \%$ of the total area in Newark Bay. In channels that are deep and flat, the sedimentation rate is moderate at $3 \mathrm{~cm} /$ year $(0.1 \mathrm{ft} /$ year $)$. USACE [10] modeling suggests that the HDP will only have small effects on sedimentation on the flats because the planned dredging will not change the configuration of the channels-it will only deepen the existing channels. Sommerfield and Chant [22] and a modeling study by Pecchioli et al. [19] suggest increased sediment deposition in the Bay due to channel deepening at the Kill van Kull and Arthur Kill.

\subsubsection{Overall Sediment Dynamics in Newark Bay}

Particle size, salinity, and velocity gradients are key factors in sediment transport within the NBSA. Burke et al. [40] indicate that the Navigation Channels act as the primary pathway for sediment transport and, once suspended, the fate of the sediments in the Navigation Channel depends on many factors, including the size of the particles and their settling velocity. Heavier particles tend to settle more quickly into the Navigation Channel bed, while finer particles that remain suspended during flood tide are caught in the gravitational estuarine circulation and transported to the northern portion of the Bay. During ebb tide, these same particles tend to settle and, depending upon conditions, deposit onto the sediment bed [15].

Water-column stratification also has important implications for sediment transport. During ebb tides, stratification is intensified, significantly reducing resuspension and encouraging suspended sediment deposition, particularly in the Navigation Channel [22]. For example, during a 2001 high-flow event on the Passaic River, Chant [16] reported increased suspended sediment concentrations within Newark Bay, and that coarser particles settled out of the seaward-flowing surface water into the landward bottom flow, effectively becoming trapped. Sommerfield and Chant [22] found that sediment deposition from a high-flow event in the Passaic River was greatest in the northern portions of the Bay, with little evidence of flood-tide-related deposition on the Subtidal Flats, and that most of the sediment influx from the Kill van Kull was not carried into the northern portion of the Bay, which led them to conclude that greater Newark Bay acts as a sediment convergence zone. This process corresponds to the dredged Bay bathymetry moving toward equilibrium of a natural, shallow state. Moreover, sediment may be deposited preferentially near and along the base of the steeply sloped edges of the Navigation Channel. Concurrently, the steep banks of the Navigation Channels may be eroded preferentially at the uphill edge with sediment transported downslope and into the toe of the Navigation Channel [10].

Sommerfield and Chant [22] also observed a short-term convergent deposition pattern based on their analysis of Be-7 in the surface sediments. There was a large range in Be-7 inventory, 0.2 to $6.7 \mathrm{pCi} / \mathrm{cm}^{2}$, with higher Be-7 inventories detected in the Navigation Channels than in Subtidal Flats. The Be-7 stations in the Navigation Channel also appeared to be responsive to a Passaic River high-flow event, with a sharp increase in inventory. In the Navigation Channels of the northwestern portion of the Bay (near the mouth of the Passaic River) and around Shooters Island in the south, Be-7 was detected to a depth of 2.4 in. In the Subtidal Flats, however, a much thinner sediment layer, less than 0.8 inches, was found to have Be-7 activity. The differences in Be-7 depth are thought to represent differences in the physical mixing present in the various areas. Seasonal deposition and bed 
reworking appear to be relatively intense in the Navigation Channels of the northwestern portion of the Bay, as well as the southern portion of the Bay around Shooters Island (where tidal currents and vessel-induced stresses are strong) compared to the shallower Subtidal Flats where biological mixing dominates [22].

\section{Conclusions}

The CSM for the NBSA has met its objectives of supporting a comprehensive understanding of the physical, chemical and biological processes influencing the fate and transport of contaminants of potential concern from sources to exposure media (water, sediment, and biota). The CSM provides an updated description of the conditions and processes in the NBSA based on the data generated from recent RI investigations and secondary data.

The NBSA's complex hydrodynamics and sediment dynamics can pose challenges to accurately quantify freshwater and sediment loadings, circulation patterns, and transport of sediments and contaminants. To quantify current, historical, and future fate and transport of contaminants in this system in support of the RI/FS, it is necessary to develop a numerical model. The processes and variables described in the CSM can guide the development and application of the numerical model.

The major aspects of the hydrodynamic and sediment transport processes within the NBSA system are summarized below:

- In the absence of strong wind forcing or large tidal gradients, the Navigation Channel displays classic estuarine, gravitational, two-layer circulation with a seaward surface flow of freshwater and a landward bottom flow of salt water. Without freshwater or atmospheric forcing, landward flow in the channels is balanced by seaward flow in the shallow tidal flats.

- A counterclockwise residual circulation is most often observed around Staten Island, although this can reverse depending on the tidal and atmospheric forcing.

- Low freshwater inputs or episodic wind and storm events can break down the classic estuarine circulation pattern generally observed in the Bay.

- The primary source of imported sediment to Newark Bay is the Kill van Kull, which may supply up to $140,000 \mathrm{MT} /$ year.

- By comparison, the Passaic and Hackensack Rivers supply about an order of magnitude less sediment than the Kill van Kull, despite being the largest freshwater sources.

- Under the existing dredged configuration, most of the sediment originating from the Kill van Kull is deposited within the southern half of the Bay; most of the sediment originating from the Passaic River is deposited within the northern half of the Bay.

- Long-term average sedimentation in Newark Bay, particularly within the dredged channels, is offset by rates of maintenance dredging.

- The Subtidal Flats have low deposition rates and appear to be in long-term equilibrium.

- The extensive history of dredging and shoreline development that have taken place in the NBSA have resulted in changing historical circulation and sediment transport patterns. Historical transport patterns are likely quite different from current transport patterns. 


\section{Acknowledgements}

Exponent thanks Tierra Solutions for supporting the development of this manuscript.

\section{Conflicts of Interest}

The authors declare no conflict of interest.

\section{References}

1. Tierra Newark Bay Study Area Remedial Investigation Work Plan. Sediment Sampling and Source Identification Program; Tierra Solutions, Inc.: East Brunswick, NJ, USA, September 2005.

2. Tierra Newark Bay Study Area Phase II Remedial Investigation Work Plan; Tierra Solutions, Inc.: East Brunswick, NJ, USA, November 2007.

3. Tierra Draft Phase I and Phase II Data Evaluation and Analysis Report. Newark Bay Study Area Remedial Investigation; Tierra Solutions, Inc.: East Brunswick, NJ, USA, March 2013.

4. Tierra Draft Data Gaps Report. Newark Bay Study Area Remedial Investigation; Tierra Solutions, Inc.: East Brunswick, NJ, USA, March 2013.

5. Meyers, W.S. The Story of New Jersey; Lewis Historical Publishing: New York, NY, USA, 1945.

6. Cunningham, J.T. Made in New Jersey: The Industrial Story of a State; Rutgers University Press: New Brunswick, NJ, USA, 1954.

7. Cunningham, J.T. Newark: Revised and Expanded; New Jersey Historical Society: Newark, NJ, USA, 1966.

8. Cunningham, J.T. New Jersey: America's Main Road; Doubleday \& Company: New York, NY, USA, 1966.

9. Brydon, N.F. The Passaic River: Past, Present, Future; Rutgers University Press: New Brunswick, NJ, USA, 1974.

10. USACE. Geomorphological/Geophysical Characterization of the Nature and Dynamics of Sedimentation and Sediment Transport in Newark Bay Focusing on the Effects Related to Continued and Future Federal Navigation Channel Deepening and Maintenance; US Army Corps of Engineers: New York, NY, USA, 2006.

11. Iannuzzi, T.J.; Ludwig, D.F.; Kinnell, J.C.; Wallin, J.M.; Desvouges, W.H.; Dunford, R.W. $A$ Common Tragedy: History of an Urban River, 1st ed.; Amherst Scientific Publishers: Amherst, MA, USA, 2002.

12. NOAA. Magnitude and Extent of Sediment Toxicity in the Hudson Raritan Estuary; National Oceanic and Atmospheric Administration: Silver Spring, MD, USA, 1995.

13. USEPA. Sediment Quality of the NY/NJ Harbor System; U.S. Environmental Protection Agency: Edison, NJ, USA, 1998.

14. Herrington, T.O.; Rankin, K.L.; Bruno, M.S. Frequency of Sediment Suspension Events in Newark Bay. In Proceedings of the International Conference Protection and Restoration of the Environment VI, Skiathos, Greece, 1-5 July 2002; pp. 371-378.

15. Wakeman, T.H., III. Effects of Changes in Sediment and Contaminant Loads in Newark Bay on Future Disposal of Dredged Sediments; Columbia University: New York, NY, USA, 2006. 
16. Chant, R.J. Hydrodynamics of the Newark Bay/Kills System; Rutgers University, Institute of Marine and Coastal Sciences: New Brunswick, NJ, USA, 2006; p. 90.

17. Pence, A.M. Dominant Forces in an Estuarine Complex with Multiple Tributaries and Free Connections to the Open Ocean with Applications to Sediment Transport; Stevens Institute of Technology: Hoboken, NJ, USA, 2004.

18. Suszkowski, D.J. Sedimentology of Newark Bay, New Jersey: An urban Estuarine Bay; University of Delaware: Newark, DE, USA, 1978.

19. Pecchioli, J.A.; Bruno, M.S.; Chant, R.J.; Pence, A.M.; Blumberg, A.F.; Fugate, D.; Fullerton, B.J.; Glenn, S.; Haldeman, C.; Hunter, E.; et al. The New Jersey Toxics Reduction Workplan for New York-New Jersey Harbor: Study I-E-Hydrodynamic Studies in the Newark Bay Complex; New Jersey Environmental Department: Trenton, NJ, USA, 2006; p. 10.

20. Blumberg, A.F.; Khan, L.A.; St. John, J.P. Three-dimensional hydrodynamic model of New York Harbor Region. J. Hydraul. Eng. 1999, 125, 799-816.

21. Chant, R.J. Secondary circulation in a region of flow curvature: Relationship with tidal forcing and river discharge. J. Geophys. Res. Oceans 2002, 107, 14-1-14-11.

22. Sommerfield, C.K.; Chant, R.J. Mechanism of Sediment Trapping and Accumulation in Newark Bay, New Jersey: An Engineered Estuarine Basin; Hudson River Foundation: New York, NY, USA, 2010; p. 40.

23. Caplow, T.; Schlosser, P.; Ho, D.T.; Santella, N. Transport dynamics in a sheltered estuary and connecting tidal straits: $\mathrm{SF}_{6}$ tracer study in New York Harbor. Environ. Sci. Technol. 2003, 37, 5116-5126.

24. USGS. Real-time data for USGS 01389500 Passaic River at Little Falls, NJ, USA. Available online: http://waterdata.usgs.gov/nwis/uv?01389500 (accessed on 9 April 2013).

25. USGS. Real-time data for USGS 01378500 Hackensack River at New Milford, NJ, USA. Available online: http://waterdata.usgs.gov/usa/nwis/uv?01378500 (accessed on 9 April 9 2013).

26. USGS. Real-time data for USGS 01395000 Rahway River at Rahway, NJ, USA. Available online: $\mathrm{http}: / /$ waterdata.usgs.gov/nwis/nwisman/?site_no=01395000\&agency_cd=USGS (accessed on 12 April 2013).

27. Bonin, J.L. Organic Compounds and Cadmium in the Tributaries to the Elizabeth River in New Jersey, October 2008 to November 2008: Phase II of the New Jersey Toxic Reduction Workplan for New York-New Jersey Harbor; US Geological Survey: Reston, VA, USA, 2010; p 27.

28. USGS. Real-time data for USGS 01393690 Morses Creek at West Stimpson Avenue at Linden NJ, USA. Available online: http://waterdata.usgs.gov/nj/nwis/measurements/?site_no=01393690 (accessed on 2 May 2013).

29. Thomas, S. Wind, Tide and Buoyancy Induced Residual Circulation in a Tidal Strait; Stevens Institute of Technology: Hoboken, NJ, USA, 1993.

30. HydroQual Inc. Assessment of Pollutant Loadings to New York-New Jersey Harbor; HydroQual: Mahwah, NJ, USA, 1991; p. 268.

31. Lowe, S.; Abood, K.; Ko, J. A sediment budget analysis of Newark Bay. J. Mar. Sci. Environ. 2005, 3, 37-44.

32. Rutgers University Monthly precipitation in New Jersey from 1895 to 2013. Available online: http://climate.rutgers.edu/stateclim_v1/data/njhistprecip.html (accessed on 8 May 2013). 
33. FindTheData Average rainfall for US cities. Available online: http://average-rainfall-cities. findthedata.org/ (accessed on 8 May 2013).

34. Pence, A.M.; Chant, R.J.; Pecchioli, J.A.; Douglas, W.S. Hydrodynamics of the Newark Bay/Kills System: New Jersey Toxics Reduction Workplan for New York-New Jersey Harbor; Rutgers University, Institute of Marine and Coastal Sciences: New Brunswick, NJ, USA, 2006.

35. Geyer, R.; Chant, R.J. The Physical Oceanographic Processes in the Hudson River Estuary. In The Hudson River Estuary; Levinton, J., Waldman, J., Eds.; Cambridge University Press: New York, NY, USA, 2006; pp. 24-38.

36. LMS. A Macro Assessment of Newark Bay Sediment Budget; Lawler, Matusky \& Skelly Engineers LLP: Pearl River, NY, USA, 2004; p. 65.

37. Chant, R.J. Circulation and Sediment Dynamics in the Newark Bay and Kills System from Moored Observations. In Sediment Transport Workshop; Suszkowski, D.J., Geyer, W.R., Eds.; Hudson River Foundation: New York, NY, USA, 2003.

38. Rankin, K.L.; Chant, R.J.; Bruno, M.S.; Glenn, S. Meteorological Forcing of the Kills in New York/New Jersey Harbor. In American Geophysical Union Fall Meeting; American Geophysical Union Press: San Francisco, CA, USA, 2002.

39. USACE. Final Environmental Impact Statement on the Newark Bay Confined Disposal Facility; U.S. Army Corps of Engineers, New York District: New York, NY, USA, 1997; p. 351.

40. Burke, P.B.; Rankin, K.L.; Herrington, T.O.; Bruno, M.S. Sediment Transport between Deep Navigation Channels and Shallow Side Banks under Variable Tidal and Meteorological Forcings. In American Geophysical Union Fall Conference; American Geophysical Union Press: San Francisco, CA, USA, 2002.

41. HydroQual. Final Modeling Work Plan. Lower Passaic River Restoration Project; HydroQual, Inc.: Mahwah, NJ, USA, 2006.

42. HydroQual. Final Modeling Work Plan Addendum; HydroQual, Inc.: Mahwah, NJ, USA, 2006.

43. van Rijn, L.C. Principles of Sediment Transport in Rivers, Estuaries and Coastal Seas; Aqua Publications: Amsterdam, The Netherlands, 1993.

44. Grant, W.D.; Madsen, O.S. Combined wave and current interaction with a rough bottom. J. Geophys. Res. 1979, 84, 1797-1808.

45. Glenn, S.M.; Grant, D.W. A suspended sediment stratification correction for combined waves and current flows. J. Geophys. Res. 1987, 92, 8244-8264.

46. Malcom Pirnie Inc. Lower Passaic River Restoration Project: Draft Geochemical Evaluation (Step 2); Malcom Pirnie Inc.: White Plains, NY, USA, 2006; p. 421.

47. Wilson, T.P.; Bonin, J.L. Concentrations and Loads of Organic Compounds and Trace Elements in Tributaries to Newark and Raritan Bays, New Jersey; USGS: Reston, VA, USA, 2007; p. 176.

48. Olsen, C.R.; Larsen, I.L.; Brewster, R.H.; Cutshall, N.H.; Bopp, R.F.; Simpson, H.J. $A$ Geochemical Assessment of Sedimentation and Contaminant Distributions in the Hudson-Raritan Estuary; Oak Ridge National Laboratory: Oak Ridge, TN, USA, 1984; p. 101.

(C) 2014 by the authors; licensee MDPI, Basel, Switzerland. This article is an open access article distributed under the terms and conditions of the Creative Commons Attribution license (http://creativecommons.org/licenses/by/3.0/). 